\title{
Editorial
}

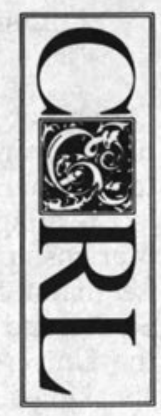

\section{Humble Enough/Wise Enough}

At an Association of Research Libraries (ARL) Conference last spring, William G. Grundstrom defined benchmarking as "the practice of being humble enough to admit that someone else is better at something, and being wise enough to learn how to match and even surpass them at it."* More traditional definitions characterize benchmarking as the search for best practices. Both benchmarking and the related practice of comparative analysis of outcomes exist under the broader concept of assessment, a buzzword on many campuses. Assessment determines the effectiveness of programs and the degree to which they meet their goals. In this editorial I recount some CERL initiatives in comparative analysis, a CERL benchmarking effort, and some Penn State efforts in those two areas. Through an improvement of practices, librarians can begin the larger task of assessing how programs meet users' needs.

CERL's Comparative Analysis. At each American Library Association (ALA) conference, the editors of the different journals published by ALA gather to hear an update from ALA Publishing and to share common concerns. Recently I used that opportunity to gather comparative information about acceptance rates and turnaround times. Member editors for Information Technology and Libraries, Library Administration \& Management, Library Resources \& Technical Services, and $R Q$ were willing to share figures on an informal basis. The results were humbling, as College \& Research $\mathrm{Li}$ braries has the longest time from acceptance to publication and the lowest acceptance rate among the divisional journals. In many disciplines low accep- tance rates and length of time to publication correlate with excellence of reputation. Nevertheless, members of the Editorial Board, member referees, and the editorial group are all working to improve turnaround times.

Articles in CERL provide a good point of departure for beginning a comparison of library practices. The genres of case studies and "how I did it well" articles often portray the successes of a single library. ACRL members use such articles as a measure for the efficiency and effectiveness of local programs. CERL referees and editors encourage authors to present results in a manner that will be relevant to the varied types of libraries staffed by ACRL members. This body of information about practices is the first place a librarian should turn in seeking to improve a process.

Another resource for preliminary information about library practices will be the developing Association for Research Libraries' benchmarking program. This program began with a grant from the Council on Library Resources to do a pilot using the interlibrary loan process to examine the applicability of benchmarking as a technique for libraries. A report will soon be available as will courses on training and facilitation for benchmarking. In response to higher education's emphasis on assessment, ARL's Statistics and Measurement Committee continues to develop access and performance measures as an adjunct or alternative to input measures.

CERL's Benchmarking. As a people, Americans are often accused of being insular, a charge to which American academic librarians are also vulnerable. The 
Dutch publisher Martinus Nijhoff International annually awards a $\$ 5,000$ grant to an American librarian to support a project relating to the study of European librarianship. This year's winner, Stephen Lehmann, coeditor of CERL's Book Review Section and a humanities bibliographer at the University of Pennsylvania, will be speaking to editors of German academic library journals to explore with them areas of common concern and interest. Lehmann will bring back to the United States not just a new perspective of a distinguished and very different tradition of library journal publishing but also insights into the processes that create those results.

Penn State's Benchmarking Efforts. Last year Penn State's Provost John Brighton required all academic units to engage in benchmarking as a part of their strategic planning initiatives. The University Libraries sought areas that were related to its strategic directions and that would allow librarians to improve the organization through comparison with others. The Libraries' Administration chose provision of electronic resources to scholars, human resource development, and interlibrary loan borrowing as being areas in which our strategic direction required excellence. Each of these areas could be clearly related to the libraries' mission and vision.

A team composed of Ron Dow, Sally Kalin, Diane Smith, and I selected the areas and determined who were the best comparators. We used comparative analysis to find libraries that were like ours in key areas, such as number of electronic databases, number of interlibrary loan borrows, and number of graduate students and faculty. We then relied on our network of professional association colleagues to provide assessments about whose programs had outstanding reputations. The institutions we approached were exceedingly gra- cious in spending time answering our prepared lists of questions and in showing us their operations. Working in one or more of the areas outlined above, we visited University of California-Los Angeles, University of Michigan, University of Pennsylvania, and University of Texas. In the area of human resource development, we engaged in generic benchmarking, working not with institutions like ours but with other organizations engaged in a similar task-educating staff and professionals. Two local companies, muRata Electronics North America and Corning Asahi, shared information about their programs with us.

In order to prepare for the actual visits, we studied our own operations extensively so that we would have data to share with our comparators. We made and tested lists of questions, created flowcharts of processes, and constructed control charts showing existing performance. We prepared ourselves to answer questions about the nature of our benchmarking expedition. We were aware of the imposition on host institutions and practiced our best guest behavior.

We were humbled. Although we consider ourselves to be one of the most exciting libraries in the country, in the areas benchmarked we can make major improvements.

Benchmarking is a difficult and relatively expensive method for improving processes and results. Careful internal planning and study are required before a successful trip can occur. However, the results of a well-planned and -executed benchmarking effort can provide dramatic improvement. Through seeking out the best practices both in libraries and outside them, librarians can improve practices and become wise enough to embrace a paradigm of continuing assessment and coordinated change.

GLORIANA ST. CLAIR

* William G. Grundstrom, " $\mathrm{C}+\mathrm{Q}+\mathrm{P} / \mathrm{M}=$ Benchmarking: $\mathrm{TQM}$ and Academic Libraries," "Total Quality Management in Academic Libraries" sponsored by Association of Research Libraries, Office of Management Services and Wayne State University, Washington, D.C., April 20-22, 1994. 